\title{
The Pragma-Crafting Theory: A Proposed Theoretical Framework for Pragmatic Analysis
}

\author{
Acheoah John Emike ${ }^{1}$ \\ ${ }^{1}$ Department of Language and Communication Studies, Faculty of Arts and Social Sciences, Federal University \\ Dutsin-Ma, Katsina State, Nigeria.
}

\begin{abstract}
This paper proposes a new theoretical framework for the analysis of discourse. Thus, this paper presents the Pragma-crafting Theory to explain discourse from a more comprehensive and integrative perspective. Insights from research in pragmatics, sociolinguistics, discourse analysis and semiotics give this study direction. Two super-ordinate concepts in the theory are EVENT and TEXT. The former consists of interactive and noninteractive participants while the latter consists of setting, theme and p-crafting features. Therefore, the theory is particularly an extension of Mey (2001). On the whole, the present study finds out that an all-encompassing analysis of communicative events presupposes the explanation of the interaction between communication acts (speech acts, segmental features, supra-segmental features, phones, exclamations, lyrical and non-lyrical music, sociolinguistic variables, drumming, semiotic particulars, etc.) and communication features such as indexicals, shared macro-knowledge, shared contextual knowledge, shared knowledge of emergent context, geoimplicature, contextual implicature and other P-crafting features.
\end{abstract}

Keywords: Pragma-Crafting Theory, Pragmatics, Sociolinguistics, Discourse Analysis, Semiotics, Mey

\section{INTRODUCTION}

Pragmatic theoretical frameworks attempt to explain what the speaker means by performing linguistic, extralinguistic and psychological acts in discourse. However, what a speaker means transcends sentence meaning. For this reason, existing theoretical frameworks do not resolve the controversy over 'sentence non-literality and 'semantic underdetermination, which are misconstrued concepts in the literature of pragmatics and speech act study. The Pragma-crafting Theory consists of categories for explaining the speaker's meaning from both sentential and extra-sentential constraints. A semantically underdeterminate sentence does not express a complete proposition (has no definite truth condition) even when no non-literal act is performed; the proposition of the sentence remains inadequate regardless of appropriate indexicals and absence of ambiguity and vagueness (see Atlass 1977; 1989 for tips on 'semantic generality; and Bach 1982 for more insights on the concept of 'non-specificity' which are related to the notion of 'semantic underdetermination').

In this paper, I propose a theoretical framework which exposes the strengths and weaknesses of the existing pragmatic theories and methodologies which are applied in the analysis of discourse. The Pragma-crafting Theory introduces new components for the pragmatic analysis of spoken and written communication. Features of immediate and remote contexts as well as the analysis of latent meanings in communicative events have not been adequately accounted for by the existing pragmatic analytical frameworks. The concepts in the theory show its interdisciplinary and integrative model. An integrative pragmatic analytical framework should be the product of insights from different domains of linguistic study. Indeed, Dijk (2003) argues that an integrative framework facilitates the choice of the relevant categories for analysis. My aim in this paper is to present the Pragma-crafting Theory as being a broad and systematic instrument for the explicit and valid pragmatic analysis of texts.

The intricate and productive relationship between grammar and pragmatic devices is worthy of scholarly attention. I establish this perspective in the proposed theory, relying on the roles of linguistic, extra-linguistic and psychological acts in discourse. Indeed, cognitive pragmatics remains a theory that is concerned with the level of competent performance demonstrated by speakers in communicative events (cf. Bosco et. al 2004). There is need for a theoretical framework that explains the linguistic and communicative competence which participants of discourse exhibit, being that 'performance' is the core of pragmatics.

\footnotetext{
${ }^{1}$ Corresponding Author: actualemike@gmail.com
} 
According to Bruno (2012) 'Communication cannot take place unless at least two agents are overtly involved in the interaction'. Speech act theory 'provides a way of talking about utterances not only in terms of their surface grammatical properties but also in terms of the context in which they are made, the intentions, attitudes, and expectations of the participants, the relationships existing between participants...rules and conventions that are understood to be in play when an utterance is made and received (Pratt 1977).' A critical study of the literature of pragmatics reveals that there are communication realities which existing theoretical frameworks for the analysis of different kinds of discourse do not sufficiently explain. Indeed, Austin (1962) submits that the total speech act in the total speech situation is the only actual phenomenon which in the last resort should be elucidated by the analyst. I attempt to address the weaknesses of predating pragmatic or speech act theories. The Pragma-crafting Theory is broad-based and situated, besides being able to account for the dynamics of human communications via various genres: drama, prose, poetry, cartoons, advertisements, sermons, speeches, proverbs, etc. The non-situated nature (Mey 2001) of various speech act theories, I observe, does not indicate that such theories have accommodated Austin's (ibid.) submission. In this study, I am indebted to predating theories whose notions have either been modified or extended to achieve the objectives of the study, particularly Mey (ibid.) ${ }^{1}$.

\section{Predating Theoretical frameworks in Pragmatics}

Pragmatic theories anchor and direct research in this field of linguistic study. I reviewed classical and contemporary pragmatic theories before evolving the Pragma-crafting Theory. In this section, I present just Mey (ibid.) which like other contemporary pragmatic theories is an improvement on the predating classical (Austin ibid.; Searle 1969; Grice 1975; Saddock 1974 as well as Bach and Harnish 1979) and contemporary ones².

\subsection{Mey's Theory}

Jacob Mey's Pragmatic Act theory (cf. Mey ibid.) is an attempt to remedy the pitfalls of Austin's (ibid.) speech act theory. Mey's theory consists of a super-ordinate term, Pragmeme, which anchors 'activity' and 'textual' components of discourse. The activity part shows the roles of the participants of discourse (interactants) while the textual part concerns the various contextual variables that interplay in discourse situations. Mey contends that his theory concentrates on the environmental constraints which determine what can be said, what is being said and what cannot be said in communicative events. The 'ipra' or 'pract' initiates a pragmatic act to realize a 'pragmeme'. Each 'pract' is simultaneously an 'allopract', that is, a specific production of a definite 'pragmeme'. The knowledge which interactants have on a communicative event as well as the effects of such an event on them in that particular context constitutes a 'pract'.

During communication, Mey explains, interactants produce speech acts, conversational acts, physical acts, psychological acts and prosodic acts which are all articulated in varied contexts: INF (inference); REF (reference); VCE (Voice); SSK (Shared Situation Knowledge); MPH (Metaphor); and M (Metapragmatic Joker). The metapragmatic joker refers to certain metapragmatic activities. Indexical expressions which are context-sensitive (repeating indexical expressions in discourse does not determine what they mean, as their meanings depend on who utters them and the situations that inform their production) and so necessitates adequate mastery of the context of an utterance is a good example of metapragmatic activity. Explaining the metapragmatic activity, Mey (ibid.) cites that the repetitive structure "What I do I do" is implicit (the meaning has to be worked out); the indexicality (indexical context) will produce the meaning through textual analysis that shows the users, receivers and contexts of communicative elements. Invariably therefore, the metapragmatic indexicality explains how pragmatic acts generate discourse.

\subsection{Acheoah's Proposed Pragma-crafting Theory}

The Pragma-crafting Theory presents discourse as systematic, predictable and understandable. I coined the term 'Pragma-crafting' from the phrase 'pragmatic crafting'. The theory therefore views discourse as a pragmatic crafting activity. Crafting has to do with the discourse strategies which participants employ in the structuring of communications. Utterances are produced through the goal-driven patterning of sentences in particular forms. It begins from the micro level as a unit of discourse, and extends to the macro level as a body of discourse. For example, conversational turns may be initiated with a topic which generates further topics, and subsequently, more speech acts, presuppositions, coherence and other discourse phenomena become naturally incorporated in the communicative event as participants express ideas meaningfully by exploring contextual nuances.

Every Pragma-crafting (P-crafting) involves illocrafting, uptake and sequel. Therefore, P-crafting is a super-ordinate pragmatic act which produces linguistic and extra-linguistic elements of communication. At different stages of a communicative event, there is a candidate for inference. At every such stage, the interactive and non-interactive 
participants explore P-crafting features (inference features): indexicals (INDXL); shared macro-knowledge (SMK); shared contextual knowledge (SCK); shared knowledge of emergent context (SKEC) geoimplicature (GI); linguistic implicature (LI); contextual presupposition (CP); behavioural implicature (BI), pragmadeviant (PD), object referred $(\mathrm{OR})$ and operative language (OL) to ascertain messages and sequels. Bosco et. al (2006) opine that conversation is a two-fold activity in which the participants form utterances that are products of shared meaning, and such utterances produce felicitous results to the communicative event. The figure below is illustrious:

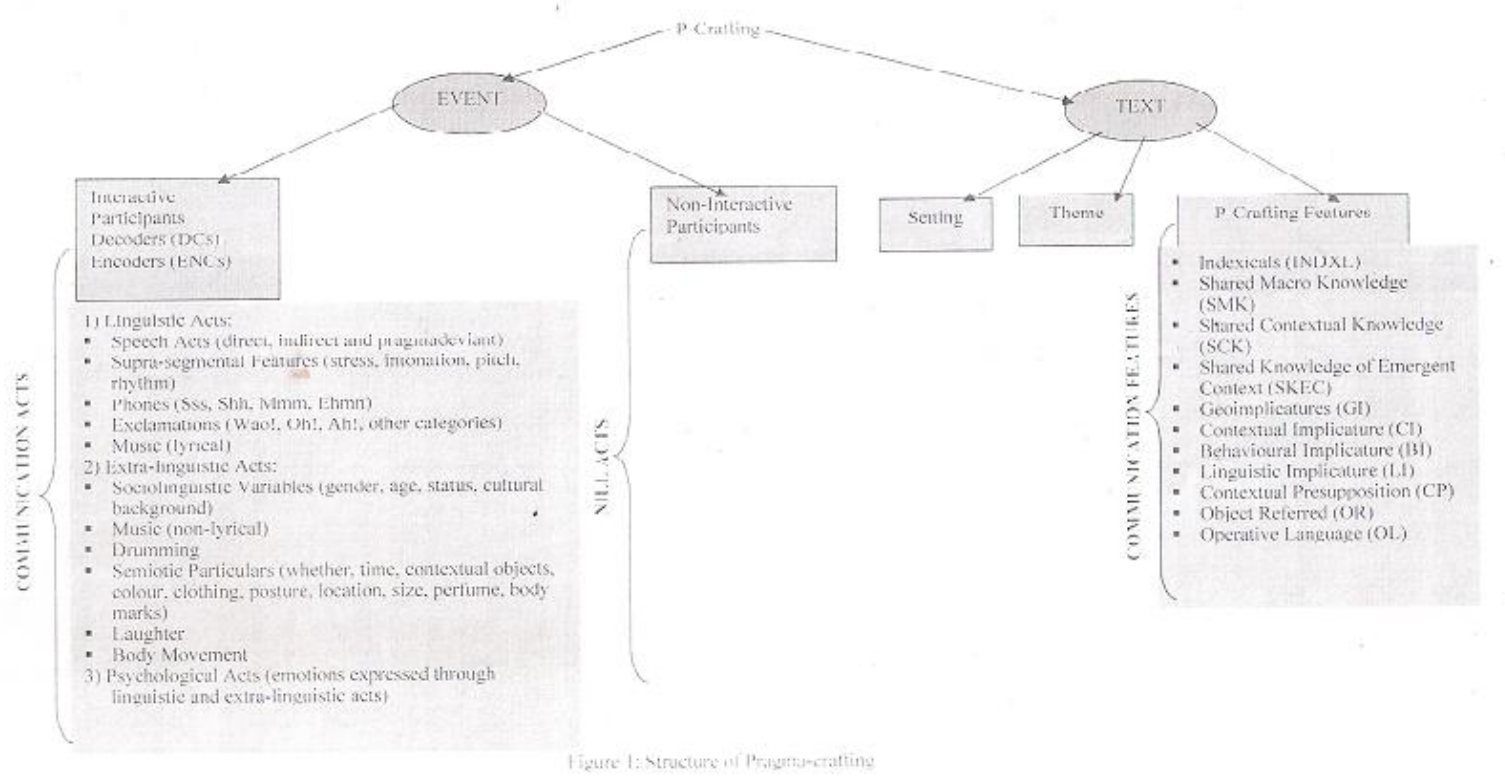

\subsection{Legends to Figures}

Figure 1, Discourse Structure of Pragma-crafting, reveals the two-fold structure of P-crafting: EVENT and TEXT. The former concerns the participants of discourse. Some of them make linguistic or extra-linguistic contributions to on-going discourse (interactive participants) whereas others do not (non-interactive participants). To participate interactively in a communicative event, the interactive participants produce linguistic, extra-linguistic (being interactive does not necessarily mean producing speech sounds; silence interacts that is, communicates messages in discourse) and psychological acts. Linguistic acts include: speech acts, segmental features, supra-segmental features, phones, exclamations and lyrical music.

Extra-linguistic acts include: sociolinguistic particulars (gender, age, status, cultural background); music (nonlyrical); drumming, gestures, dance, semiotic particulars (weather, contextual objects (CO), colour, dressing, location, size, shapes and body marks); and silence. Psychological acts are the discourse emotions expressed through linguistic and extra-linguistic acts. The three major categories of acts in EVENT are candidates for P-crafting. Pcrafting features are the tools for interpreting the linguistic, extra-linguistic and psychological acts, although SETTING and THEME also facilitate this process of interpretation. I use SETTING to refer to the physical context revealed by TEXT, and this is an optional category as some texts are not SETTING- revealing. By THEME, I mean the message(s) revealed in TEXT through topic-suggestive words and P-crafting features. On the whole the Pragmacrafting Theory shows that indeed, 'communicative acts (CA)' (I have differentiated this term from speech acts) used in EVENT) interact with 'communicative features' (CF). Thus, linguistic, extra-linguistic and psychological acts are 'communicative acts' whereas P-crafting features are 'communicative features'.

\subsection{Theoretical Concepts}

The Pragma-crafting Theory is anchored by the following concepts: 


\section{(i) P-crafting}

This is a super-ordinate notion which has dual components: Event and Text; these two components unfold as discrete multiple categories in the explanation of how communication is interpreted from speaker-hearer or writerreader ends. Therefore, I present the Pragma-crafting notion as an umbrella-term to explain the rule-governed and systematic nature of discourse.

\section{(ii) Event}

It concerns participants of discourse who are either interactive or non-interactive. The interactive participants perform any or all of these acts to the discourse: linguistic, extra-linguistic and psychological acts. On the other hand, the non-interactive participants are those who are present in the setting, but do not perform any act in the discourse. This kind of participants is typical of certain discourse settings. Even when they perform linguistic, extralinguistic or psychological acts that are not connected to the on-going discourse, I label them as non-interactive participants. For example, Billy, Gerald and Jane may begin a conversation from school and sustain it until they get to Hardy's shop, only to meet Hardy and his customer bargaining over the price of certain commodities. In this situation, all acts performed are only meaningful in terms of how they affect an on-going discourse. In another vein, the students in a classroom lecture are fragmented: some are discussing issues unrelated to the lecture; some are making linguistic, extra-linguistic and psychological contributions related to the lecture and others are just physically present in the setting. However, in certain discourse situations, an interactive participant may perform linguistic, extra-linguistic or psychological acts as an indirect communicative strategy targeted at a non-interactive participant towards achieving certain goal(s). The potential of the non-interactive participant to affect communicative events is not a debate. For example, the sociolinguistic particulars (age, status, ethnic background) of the non-interactive participants determine how and what Billy, Gerald and Jane says in Hardy's shop. For insights on the roles of the non-interactive participants in discourse, see Acheoah (2014) where the label, $\mathrm{H}_{2}$, is used to refer to participants who are present in discourse, but are not speakers' interlocutors.

\section{(iii) Text}

Components of Text are Setting, Theme and P-crafting Features. The trio constitutes the communicative features in Text. However, the dynamics of communication are captured by P-crafting Features which has discrete theoretical notions demonstrated by the interactive participants in three different frames: linguistic acts, extra-linguistic acts and psychological acts.

\section{(iv) Interactive participant}

This is an interlocutory participant. He makes linguistic, extra-linguistic and psychological contributions that do not only impinge on the interpretive process in discourse, but also determine or generate sequel. An interactive participant demonstrates pragmatic awareness in the encoding and decoding of utterances. Pragmatic awareness, Verschueren (2000) submits, is "highly important in the generation and negotiation of meaning". When contextual clues inform speakers' selection of speech acts, pragmatic awareness is demonstration. See Clark (1979) for tips on how native and non-native speakers exhibit pragmatic competence.

\section{(v) Non-interactive participant}

A participant is categorized as non-interactive when he does not function in on-going communicative event, although he is intentionally or accidentally present in the physical context. This kind of participant is rare in casual speech event (informal discourse), but are typical of places where social or institutional acts are performed: courtroom and church.

\section{(vi) Setting}

This is the physical context of the communicative event (Text) in both remote and immediate sense. A pragmatic analyst can infer from available pragmatic data, that a communicative event is not merely situated in Nigeria (macro-context), but in a domestic context (micro-context). These discourse realities determine the performance and interpretation of linguistic, extra-linguistic and psychological acts by the interactive participants.

\section{(vii) Theme}

This category is the message conveyed in/by Text. Text may convey one or more themes that can only be identified when communicative acts (acts performed by interactive participants) interact with communicative features (Pcrafting Features). 


\section{(viii) P-crafting Features}

These elements are instrumental to understanding the interlocutory roles of the interactive participants. The elements include: indexicals (INDXL); shared macro-knowledge (SMK); shared contextual knowledge (SCK); shared knowledge of emergent context (SKEC) geoimplicatures (G); linguistic implicature (LI); behavioural implicature (BI), contextual presupposition (CP); pragmadeviant (PD), object referred (OR) and operative language (OL).

Inference (INFR) has to do with making logical conclusions from available contextual data. It invariably presupposes deductive reasoning on the part of the listener, so as to arrive at speaker-meaning. This is a vital pragmatic process, because speaker meaning may not be literal.

Indexicals (INDXL) are grammatical categories that have the potential to establish the relationship between language and context. They facilitate the interpretation of utterances and give meaning to such utterances. They include demonstratives, first and second person pronouns, tense, specific time and place adverbs like now and here, and a variety of other grammatical features and a variety of other grammatical features tied directly to the circumstances of utterance (Levinson 1983:54) ${ }^{3}$.

Participants of discourse have common knowledge about global conventions across facets of life. Such background knowledge forms the basic presuppositions already resident in them before any communicative event. Shared macro-knowledge (SMK) is therefore the totality of what the participants of discourse understand as states-of-affairs in the larger society, rather than in their immediate society.

The Pragma-crafting Theory presents shared contextual knowledge (SCK) as the available pieces of information which only participants of the present discourse have for the communication to thrive.

When discourse has an emergent context, perlocutionary effects may not occur (effects intended by speakers), despite the appropriateness of participants and circumstances. Any situation that suddenly emerges in an on-going discourse is emergent. When it becomes known by those involved in the discourse, I regard it as shared knowledge of emergent context (SKEC). It is vital in terms of its potential to determine illocutionary forces and relocate sequel. An emergent context is a candidate for inferences.

In a previous study, I evolved the term 'geoimplicature' from 'geographical' and 'implicature' to refer to practices that have geographical restriction in terms of people, and not just in terms of physical boundaries. Such practices are not universal, and they are both verbal and non-verbal. Geoimplicatures those practices that are geographically restricted. The Pragma-crafting Theory strongly contends that geoimplicatures are crucial components of the interpretive process in discourse. See Acheoah (2012) for more insights on the implications of geoimplicatures in cross-cultural pragmatics.

Linguistic implicatures (LI) are meanings implied through language while behavioural implicature (BI) are meanings implied through extra-linguistic and psychological acts. Contextual presuppositions (CP) are products of shared contextual knowledge (SCK); in a specific (micro-context) discourse, participants deduce meanings from verbal and non-verbal data limited to the participants themselves. The meanings deduced are treated as background assumptions (BAs) which direct interlocutory roles. DCs (decoders) imply that ENCs (encoders) know that certain VEs (verbal elements) \& NVEs (NVEs) are deduced as OR (object referred) in OL (the Operative Language).

P-crafting features are essentially the amalgam of the pragmatic competence demonstrated by the interactive participants of discourse. Dijk (1977) posits that the comprehension of the illocutionary force of utterances, especially indirect speech acts, is a core mark of a language user's pragmatic competence.

\section{(ix) Linguistic Acts}

There are five components in this category:

- Speech acts (direct, indirect and pragmadeviant);

See Austin (ibid.) as well as Bach and Harnish (ibid.) which clearly explain that unlike direct speech acts, indirect speech acts make propositions that have additional meanings (primary) to what is secondarily meant.

Pragmadeviants are deviant forms of expressions which participants use as part of illocutionary strategy or creative indulgence. 
Acheoah 2011 coins the term 'pragmavediant' (PD) from 'pragmatics' and 'deviant'. It is not a duplication of the notion of indirect speech act as it is any expression used as a literal but deviant communicative strategy. For example, a teacher may select unacceptable formal properties of the language of instruction so as to facilitate easy comprehension of what is being taught to pupils at the lower primary school. Consider:

Teacher: Pupils, what is the function of our skeleton? (Acceptable)

Pupils: (No response)

Teacher: Pupils, what do we use our skeleton to do? (Unacceptable)

Pupils: We use it to support our body.

Teacher: Clap for yourselves.

The object referred is the referent of an utterance. This referent is either in the remote world or immediate context of speech. One of the strengths of 'meaning as object' (an approach to the study of meaning in semantics) is that words have or pick referents (objects) in the world.

Every discourse in natural communication is conveyed through a particular language, whether indigenous or alien to the participants. This is what I label operative language (OL). The pragmatic analyst is interested in cross-cultural pragmatics that bedevils the operative language in the particular text being analyzed. See Acheoah (2013a; 2013b) for illuminating perspectives on the pragmatics of the Nigerian context in utterance meanings ${ }^{4}$.

The sound qualities of consonants and vowels can be consciously altered by participants of discourse to convey various attitudes. This is of pragmatic relevance.

- Supra-segmental Features (stress, intonation, rhythm, pitch);

Stress is the degree of emphasis with which a syllable is uttered. Intonation is the rising and falling of the voice during speech production. These prosodic features convey messages in communicative events.

- Phones (Ssss, Shhh, Mmmm, Ehmnn);

I have used the term 'phones'for speech features between the phoneme and the word. They are common components in both written and spoken discourse. Small as they are, they express emotions of various kinds besides having speech acts illocutionary potential in context. For example, in Nigeria nursing mothers utter 'Ssss' as a directive (speech act) to make their infants urinate.

○ Exclamations (Wao!, Oh!, Ah!, Abah!, other categories);

Psychological acts are sometimes performed through exclamations. In this study, I present exclamations as a grammatical category which predating frameworks do not emphasize.

- Music (lyrical).

I am aware that participants can sing without using words (lyrics). However, it is when words are used that it can be said that a linguistic act has been performed. Lyrics convey diverse messages in discourse. Sometimes, the context in which a participant of discourse sings, and how it is rendered, determines the implicature. Thus, unlike previous theoretical frameworks, the Pragma-crafting Theory submits that the Gricean maxims can also be explained via musical roles in discourse rather than restricting such an explanation to a conversational structure.

\section{(x) Extra-linguistic Acts}

Extra-linguistic acts in the Pragma-crafting Theory include:

- Sociolinguistic Variables (age, cultural background, social status/class, gender, relationship);

Oloruntoba-Oju (1999: 131) observes that the elderly tend to be conservative in language use being unable to cope with the rate of language shift. These elderly ones are said to be better in rhetoric, since their speech is laden with philosophy, aphorisms and proverbs. The young on the other hand, are able to explore the phonological features of language.

The participants of discourse are from different ethnic or socio-cultural background. This situation impinges on choice of words and manner of communication. For example, one can easily say a speaker is from a particular sociocultural region of a country because of the ideologies such a region. A lot of implicatures in discourse do not 
corroborate Griceans conversational or conventional implicatures. Rather, they corroborate geoimplicature (G) (immediate socio-cultural nuances, values, beliefs and practices) in the Pragma-crafting Theory.

People are conscious of their status in communicative events. Therefore, the features of communication that is informed by status or class include adoration, supremacy, formality and informality. Status is easily noticed spoken discourse, because most writings express relationship with formal features. Status is a flexible sociolinguistic variable since relationships are not stable but changes with specific situations. Obviously, extra-linguistic acts interact with linguistic acts. For example, a participant's status can be registered though phonological features of speech. This is not captured in existing frameworks in spite of its potential to produce a comprehensive analysis. One can locate the setting of a particular discourse as well as the class and ethnic background of its participants though ethnically stigmatized speech forms.

The phrase, 'gender preferential differences' is used in sociolinguistics to explain choices made by speakers according to sex. Women are said to be more active than men in playing supportive roles in conversation, so that the speaker feels she is being listened to. Gender issue helps explain component such as shared macro-knowledge, contextual implicature and contextual presupposition in P-crafting features. If in a text, a man plays dominant gossip role, it is of pragmatic importance to the textual analyst who knows (INFR) that an implicature(s) is built therein.

Relationships that obtain in discourse determine choice of linguistic, extra-linguistic and psychological acts. Besides, it makes clear what is either presupposed or implied. Relationship may be formal, informal, occupational, master-servant, etc.

\section{○ Music (non-lyrical);}

Non-lyrical music operates as non-verbal communication. It can be rhythmic, but its importance in the Pragmacrafting Theory is its communicative value in discourse. Sounds produced in rhythmic pattern in certain contexts may negate world knowledge, and so becomes an implicature or an illocutionary strategy.

○ Drumming;

Where a group of students are writing an examination, drumming generates a Behavioural implicature (BI), which is produced when extra-linguistic acts negate the context of discourse. I therefore establish a breakaway position from most neo-Gricean theorists who restrict implicatures to the Gricean categories: conventional and conversational implicatures (see Grice ibid.).

- Semiotic particulars (weather, time, contextual object (CO), colour, clothing, posture, perfume, location/position, size, body mark and silence);

Semiotics is a wide field of language study. It embraces almost every aspect of human interaction as almost anything in the society can be a significant sign meaningful to the special community, even if it is ideologically coded (cf. Barthes 1967). For a comprehensive analysis of texts, the symbols, signs and icons which have socio-cultural relevance need to be considered. Hawkes (1977) opines that what semiotics has discovered is that the major constraints of any social practice lie in the fact that it signifies. In other words, "every speech act includes the transmission of message through the languages of gesture, posture, clothing, hairstyle, perfume, accent, social context, etc. over and above, under and beneath, even at cross purposes with what words actually say" (ibid., 125).

\section{$\circ$ Laughter}

Laughter is capable of conveying expected emotions of solidarity, peace, approval, admiration, etc.

○ Body Movement

Not all body movements are gestures. Like gestures, body movement can reveal psychological states of participants, besides being able to achieve communicative goals.

(xi) Psychological Acts: These are the different emotions expressed through linguistic and extra-linguistic acts.

\section{A Sample Analysis}

In this section I use the Pragma-crafting Theory to analyze a micro-structure from Eniola Goes to School ${ }^{5}$. I divide the structure into six utterances (henceforth U.1 - U.6) for easy referencing:

\subsection{Presentation of Data}

The data are presented below: 
U.1 Mrs. Adegbite: (Stopping Eniola's remark abruptly as she picks up a phone call) 'Shhh. Tvhank you Mr. Mmmanager! We are not surprised that you mmmanage the company efficiently. No wonder you have enough certificates, even in disciplines the world is yet to know. Only well-managed companies fold up. That is why our company, Trox Investments Plc., is crumbling under your managerial ability, with no insurance company to rescue us from the mess.'

U.2 Eniola: (With both hands on her mouth) 'Ah! Mum, do I still have hope? The bucket, cutlass, sandals, mattress, are to prepare me for a long academic journey in the secondary school. Bereaved of my father, you are my only hope. I heard it ...'

U.3 Mrs. Adegbite: (Agitating with a loud voice which gradually lowers) 'Eniola, my daughter. I am nnnot a Mama Gee. I even heard that the entire villagers are saying that your consolation prize is that you have a mother who is not an MG like some of the other widows, and so will not abandon her children to pay the expensive bills of a young satisfaction-giving man.'

U.4 Trader: (Stretching a small stove towards Mrs. Adegbite) 'Have this also. It goes for just three hundred and fifty naira.'

U.5 Mrs. Adegbite: (Looking at Eniola and both laughing) 'Students do not cook in the hostels,' Adam said, as she turned towards the trader's friend who has been sitting inside the shop, paying no attention to the conversation.

U.6 Preye: (A middle-aged man who suddenly appears on the scene, holding a small fishing net, some hooks, and wearing a hat and wet, tattered clothes as he stretches his hands proudly and very extensively towards Trader). 'Some good catch! Prepare my favourite meal while I visit my daughter's uncle to know why her performance in Mathematics has not been encouraging. Some teachers in that school still believe that the uncle is a good Mathematics teacher. She needs Mathematics to cope with science subjects when she gets into the secondary school.'

\subsection{Analysis}

Acts performed in U.1-U.6 and their pragmatic crafting features are analyzed as follows ${ }^{6}$ :

\begin{tabular}{|c|c|c|c|c|}
\hline $\begin{array}{l}\text { Utteranc } \\
\text { e }\end{array}$ & Linguistic Act & \begin{tabular}{|l} 
Extra-linguistic \\
Act
\end{tabular} & $\begin{array}{l}\text { Psychological } \\
\text { Act }\end{array}$ & Pragmatic Crafting Features \\
\hline U.1 & $\begin{array}{l}\text { (a) Speech Acts: } \\
\text { - Disputative(Ind } \\
\text { irect) } \\
\text { - Ascriptive } \\
\text { (Indirect) } \\
\text { (b) Phone } \\
\text { ("Shhh") } \\
\text { (c) Segmental } \\
\text { Features } \\
\text { ("Mmm" and } \\
\text { "mmm" in } \\
\text { "Manager" and } \\
\text { "mmmanage" } \\
\text { respectively) }\end{array}$ & $\begin{array}{l}\text { Sociolinguistic } \\
\text { Variable (status): } \\
\text { The encoder is a } \\
\text { working class } \\
\text { literate. }\end{array}$ & Disgust & $\begin{array}{l}\text { The encoder is neither thanking nor commending her } \\
\text { interlocutor. Rather, she is mocking him. The qualities she } \\
\text { ascribes to this interlocutor is an expression of disgust. The } \\
\text { phone "Shhh" is used because a longer stretch of utterance } \\
\text { will be a delay since the call came in unexpectedly amidst a } \\
\text { conversation between Mrs. Adegbite and her daughter, } \\
\text { Eniola, who is not embarrassed for being stopped abruptly; } \\
\text { shared knowledge of this emergent context (SKEC) } \\
\text { relocates the perlocutionary act (sequel) which would have } \\
\text { been "embarrassment". The articulation of the bilabial } \\
\text { plosive /m/ is to demonstrate the intense disgust which the } \\
\text { encoder feels towards the manager. The operative language } \\
\text { of the communication (OL) which is English, does not } \\
\text { accept such duplication of same consonantal phoneme. The } \\
\text { object referred (OR) is the predisposition of the Manager, } \\
\text { and this object is a product of shared contextual knowledge } \\
\text { (SCK) from working or office relationship. It is implied that } \\
\text { the encoder's interlocutor is egocentric and domineering } \\
\text { (contextual implicature). Speaking from world } \\
\text { knowledge/shared macro-knowledge (SMK), we expect the } \\
\text { encoder to respect her boss. Her manner of interaction with } \\
\text { this boss implies that she has little or no regard for him. We } \\
\text { know this boss is male through the linguistic implicature } \\
\text { (LI) of the title "Mr." }\end{array}$ \\
\hline U.2 & $\begin{array}{l}\text { (a) } \text { Speech Acts: } \\
\text { - Question } \\
\text { (Direct) } \\
\text { - Assertive } \\
\text { (Direct) } \\
\text { - Informative(D) } \\
\text { irect) }\end{array}$ & $\begin{array}{l}\text { Semiotic } \\
\text { Particulars } \\
\text { (gesture): both } \\
\text { hands on the } \\
\text { mouth }\end{array}$ & Surprise & $\begin{array}{l}\text { The encoder asks if she still has hope of being sponsored in } \\
\text { school. She asserts that her future is precarious unless her } \\
\text { mother can cope with sponsoring her education. She } \\
\text { informs her mother that she heard part of what was said } \\
\text { during the phone call. The exclamation "Ah!" conveys her } \\
\text { surprise over what was heard. The participants' disposition } \\
\text { and topic of discourse have changed due to their shared }\end{array}$ \\
\hline
\end{tabular}




\begin{tabular}{|c|c|c|c|c|}
\hline & $\begin{array}{l}\text { (b) Exclamation } \\
\text { (Ah!) }\end{array}$ & & & $\begin{array}{l}\text { knowledge of the emergent context (SKEC). The encoder is } \\
\text { no longer emotionally stable. }\end{array}$ \\
\hline U.3 & $\begin{array}{l}\text { (a) Speech Act: } \\
\text { - Responsive } \\
\text { - Informative } \\
\text { (b)Supra- } \\
\text { segmental } \\
\text { Feature (falling } \\
\text { pitch) }\end{array}$ & $\begin{array}{l}\text { Semiotic } \\
\text { Particulars } \\
\text { (contextual } \\
\text { objects): bucket, } \\
\text { cutlass, mattress } \\
\text { and sandals }\end{array}$ & $\begin{array}{l}\text { Worry and } \\
\text { Surprise }\end{array}$ & $\begin{array}{l}\text { The encoder responds to her daughters worry and informs } \\
\text { her that she is able to provide the needed support. The rise- } \\
\text { fall intonation demonstrates deep mother-child affection } \\
\text { meant to control the decoder's emotion. The contextual } \\
\text { objects suggest the relationship between the participants } \\
\text { and the purpose of the discourse; it is a family relationship } \\
\text { in which a mother buys school materials for her child who } \\
\text { has just secured admission into a secondary school. The } \\
\text { expressions "Mama Gee" and "MG" are geoimplicatures } \\
\text { because the object referred when they are uttered in this } \\
\text { speech community (the theme of immorality that pervades } \\
\text { the society) is of speaker-hearer shared knowledge. }\end{array}$ \\
\hline U.4 & $\begin{array}{ll}\text { (a) } & \text { Speech Acts: } \\
\text { - } & \text { Offer (Direct) } \\
\text { - } & \text { Informative } \\
& \text { (Direct) }\end{array}$ & \begin{tabular}{l|} 
(a) Semiotic \\
Particulars \\
(gesture): \\
stretching of hands \\
(b) Sociolinguistic \\
Variable \\
(relationship): The \\
participants have \\
seller-buyer \\
relationship.
\end{tabular} & Eagerness & $\begin{array}{l}\text { The encoder offers to sale a commodity, and so informs the } \\
\text { buyer about the price. This encoder is anxious to sale her } \\
\text { commodities, and so uses a non-verbal act alongside verbal } \\
\text { acts to achieve her intention, although the buyer does not } \\
\text { request the commodity. The } \\
\text { expression "also" is uttered with contextual presupposition } \\
\text { (CP); Trader presupposes that Mrs. Adegbite knows that } \\
\text { she had already taken one or more commodities from the } \\
\text { trader before. }\end{array}$ \\
\hline U.5 & $\begin{array}{l}\text { (a) Speech Act: } \\
\text { Informative }\end{array}$ & $\begin{array}{l}\text { (a) Laughter } \\
\text { (b) Body } \\
\text { movement } \\
\text { (looking and } \\
\text { turning) }\end{array}$ & Amusement & $\begin{array}{l}\text { The encoder informs her interlocutor that students do not } \\
\text { need stove in school. The extra-linguistic acts are informed } \\
\text { by shared macro knowledge that boarding house students in } \\
\text { secondary schools are not allowed to cook in the dormitory. } \\
\text { Mrs. Adegbite and Eniola are amused that Trader is } \\
\text { bereaved of this general knowledge. The participants' } \\
\text { attitude is altered by their shared knowledge of the } \\
\text { emergent context (SKEC). The extra-linguistic act of } \\
\text { turning towards the trader's friend does not yield a sequel } \\
\text { because this friend is a non-interactive participant. }\end{array}$ \\
\hline U.6 & $\begin{array}{l}\text { (a) Speech Acts: } \\
\text { - Informative(D } \\
\text { irect) } \\
\text { - Requestive } \\
\text { (Direct) } \\
\text { (b)Exclamation } \\
\text { (Some good } \\
\text { catch!) }\end{array}$ & $\begin{array}{l}\text { (a)Body } \\
\text { Movement } \\
\text { (stretching of } \\
\text { hands proudly) } \\
\text { (b)Sociolinguistic } \\
\text { Variables(age, } \\
\text { gender) } \\
\text { (c)Semiotic } \\
\text { Particulars } \\
\text { (contextual } \\
\text { objects, clothing) }\end{array}$ & Excitement & $\begin{array}{l}\text { The encoder informs his interlocutor that he caught fish, } \\
\text { and requests that she prepares meal and get him his clothes. } \\
\text { It is uttered with excitement because the encoder feels he is } \\
\text { skillful (no wonder he proudly stretches forth his hands } \\
\text { extensively instead of moving closer to Trader) and can } \\
\text { have good meal. The exclamation mark is suggestive of his } \\
\text { emotion. It can be inferred that the man is the husband of } \\
\text { Trader considering the sociolinguistic variables of being a } \\
\text { male and being middle aged. Shared macro knowledge } \\
\text { (SMK) can be used to infer that all over the world middle- } \\
\text { age is a marriageable age; this interactive participant cannot } \\
\text { be the husband of Trader if he were a five-year old male. } \\
\text { The semiotic particulars (contextual objects) communicate } \\
\text { messages in the text: "fishing net" and "hooks" show that } \\
\text { this encoder is a fisherman who is just returning from where } \\
\text { he went to fish; the tattered, wet clothes he wears shows } \\
\text { that he is not just a fisherman but is indeed, just returning } \\
\text { from fishing. The expression "uncle" is understood by the } \\
\text { decoder despite the fact that the encoder uses it } \\
\text { connotatively to mean "teacher". The inference is made } \\
\text { possible because of encoder-decoder shared knowledge in } \\
\text { the form of geoimplicature. People in this speech } \\
\text { community understand that the objects referred (ORs) when } \\
\text { the expression is uttered are both the denotative and } \\
\text { connotative senses. In Trader decodes the object referred } \\
\text { via contextual implicature (the context in which the encoder } \\
\text { uses it). }\end{array}$ \\
\hline
\end{tabular}




\section{Discussions}

The study establishes the following:

$>$ There is some link between uptake and sequel;

$>$ A clear-cut difference abounds between an illocutionary act and a perlocutionaary act;

> Perlocutionary acts are not predictable, but can be 'calculated'.

Although I establish the EVENT-TEXT dichotomy, I do not ignore the fact that the interactive and non-interactive participants are part of TEXT. Hence, I evolve the concepts, 'contextual implicature' (CI) and 'contextual presupposition' (CP) for the elucidation of intricate discourse realities. The former refers to meanings that can be calculated from the linguistic, extra-linguistic and psychological acts of interactive participants while the latter has to do with things taken for granted by participants of discourse in the performance of linguistic, extra-linguistic and psychological acts. At this juncture, it is clear that even the non-interactive participants (those present in SETTING as a matter of necessity rather than performing propositional roles) are aware of the presuppositions and implicatures that operate in discourse. (GI) is decoded through a more extra-textual reference, although the three concepts have external relations through the application of SMK; for S (speaker) to presuppose that $\mathrm{H}$ (hearer) understands a given LEPa (linguistic, extra-linguistic and psychological act) in C (Context), $\mathrm{S}$ relates such an act to states-of-affairs in the world; that is, S takes H's world knowledge or socio-cultural knowledge for granted. Similarly, to work out what a given LEPa means, H makes reference to states-of-affairs either in the larger society (world knowledge) or in his immediate society (socio-cultural knowledge). Thus, geoimplicature is different from macro shared knowledge. The former explains activities or social realities in the immediate environment (speech community) whereas the latter explains activities, practices or social realities in the world at large.

I strongly hold the view that the Pragma-crafting Theory helps the pragmatic analyst to discover hidden dimensions of meaning in discourse (implicit, presupposed and inferred meaning). Classical pragmatic theories overemphasized speech act taxonomy beyond the dynamics of natural communication. Objecting to speech act theory, Sperber and Wilson $(1986,244)$ argue that speech act taxonomy is not part of what is communicated, and so does not play a 'necessary role in comprehension'. The Pragma-crafting Theory corroborates Sperber and Wilson (ibid.) in the sense that it presents the P-crafting features as being paramount as the relevance and comprehension of speech acts and other acts performed in discourse depend on the extent to which components of the P-crafting features are utilized pragmatically by participants; the communicative relevance or meaning of a sentence (speech acts) depends on the indexicals therein. Sperber and Wilson (ibid.) submit that speech act classification may be 'invented' to formulate theories about utterances or may be formulated on the basis of native speakers' own classification of such utterances. I acknowledge that some notions in the Pragma-crafting Theory are informed by the knowledge of speech act types. For example, a participant can use lyrical music as an indirect speech act to mock another participant; the context and manner of the performance is always suggestive to the participant who is being mocked.

A pragmatic speaker uses his/her pre-knowledge of the grammatical and semantic properties of language to 'shift' or 'pragmadeviate' onto speaker-based pragmatic choices. For example, the encoder of the expression 'uncle' in U.7 is aware of the denotative meaning of the word but pragmadeviates into context-informed connotative meaning.

\section{Conclusions}

The Pragma-crafting Theory shows that utterances in discourse are understood when linguistic clues interact with extra-linguistic factors. Abott (2000) shares this view in his treatment of the problems of pragmatic presuppositions. Knowledge of the language is insufficient for communicative competence. Meanings and felicitous results are produced in discourse when linguistic agencies appropriately refer to states of affairs in both remote (macro shared knowledge) and immediate sense (geoimplicatures). Trosborg (1995) notes that lack of grammatical competence, inhibits pragmatic use of language, which he calls "linguistic action".

Theoretical concepts in the Pragma-crafting Theory illustrate that communication involves making inferences, and this is a pragmatic process. At every stage in discourse, contextual nuances are paraded; context is indeed, dynamic. It is the level of pragmatic awareness or competence of a participant that determines how he employs pragmatic inference in changing contexts. Mejías-Bikandi (2009) asserts that "different contexts trigger different pragmatic inferences." 


\section{Endnotes}

I hinge on Bach and Harnish's speech act classification for the textual analysis done in this study. Some speech act categories in Bach and Harnish (ibid.) are assertives, informatives, assentives, dissentives, ascriptives, discriptives, disputatives, etc. However, efforts of Austin (ibid.) on notions such as locutionary, illocutionary and perlocutionary, direct and indirect acts also give this study directions.

$>$ The present project is not a critique of pragmatic theories. It is therefore not crucial to present a comprehensive work of any of the theories here. But see Acheoah (2011) for critical perspectives on the strength and weaknesses of pragmatic theories.

$>$ I do not mention indexicals in the textual analysis. It should be noted that they anchor all that is said about linguistic, extra-linguistic and psychological acts which are only of pragmatic relevance when related to the pronouns and other indexicals in U.1-7.

Acheoah $(2013 \mathrm{a} ; 2013 \mathrm{~b})$ focus on meanings within the Nigerian locale. This study is also illuminating as touching pragmadeviants.

$>$ Eniola Goes to School is the manuscript of a playlet by Wasiu Ademola. Most of the concepts and theoretical positions of this project evolved from a critical overview of how language operates interestingly in the playlet. Thus, the playlet predates this theoretical proposal. The wide range of genres that can be analyzed using the Pragma-crafting theory cannot be analyzed in this study due to space constraints.

The tabular form of analysis is optional.

\section{REFERENCES}

[1] Abott, Barbara. (2000). "Presuppositions as nonassertions.” Journal of Pragmatics, 32:1419 1437.

[2] Acheoah, John. (2011). "A Pragmatic Analysis of Ayi Kwei Armah’s The Beautyful Ones Are

[3] Not Yet Born and Ola Rotimi's Hopes of the Living Dead."PhD Dissertation. Zaria, Ahmadu Bello University.

[4] (2012). "Geoimplicatures: Critical Perspectives on Cross-cultural and Intra-cultural Pragmatics."Online International Journal of Arts and Humanities, Volume 1, Issue 4: 4350.

[5] (2013a). "Towards an Extra-Linguistic Critique of J.L. Austin's Speech Act Theory."International Journal of Applied Linguistics \& English Literature, Vol. 2 No. 5: 241248.

[6] (2013b). Saying x: The Pragmatics of a Nigerian Context."Studies in Literature and Language Vol. 6, No 3: 39 44

[7] (2014). "The Illocutionary Frames Principle (IFP) and the Austinian Postulations: A Clause-structure Investigative Discourse." Global Journal of Human and Social Sciences, Volume 13, Issue 13, Version 1.0, pp. 2129.

[8] Atlas, Jay. (1977). "Negation, Ambiguity and Presupposition.” Linguistics and Philosophy 1: 32136.

[9] Austin, John. (1962). How To Do Things With Words. Cambridge: Harvard University Press.

[10] Bach Kent and Harnish, Robert. (1979). Linguistic Communication and Speech Acts. Cambridge: Massachusetts. The MIT Press.

[11] Bach, Kent. (1982). "Semantic Nonspecificity and Mixed Quantifiers. Linguistics and Philosophy 4: 593605.

[12] Barthes, Roland. (1967). Elements of Semiology. London: Cape.

[13] Bosco, Francesca, Monica, Bucciarelli and Bruno, Bara. (2004). "The Fundamental ContextCategories in Understanding Communicative Intentions." Journal of Pragmatics 36: 46748.

[14] Bruno, Bara. (2012). "Intercultural Pragmatics." De Gruyter Mouton, 9(4): 544.

[15] Clark, Hull. (1979). "Responding to Indirect Speech Act." Cognitive Psychology 11: 43077.

[16] Dijk, Van. (1977). "Context and Cognition: knowledge Frames and Speech Acts Comprehension." Journal of Pragmatics 1: 21132.

[17] (2003). 'The Discourse-Knowledge Interface.' In: G. Weissss and R. Wodak (eds).

[18] Critical Discourse Analysis: Theory and Interdisciplinarity. Basingstoke: Palgrave Macmillan, 85 109.Grice, Hubert. (1975). "Logic and Conversation.”In: Cole and Morgan. (eds).

[19] Hawkes, Terence. (1977). Structuralism and Semiotics. London: Methuen. 
[20] Mejías-Bikandi, Errepel. (2009). “Conditional Sentences and Mood in Spanish.” Journal of Pragmatics, 41: 163172.

[21] Mey, Jacob. (2001). An Introduction to Pragmatics. Oxford: Blackwell Publishing.

[22] Oloruntoba - Oju, Taiwo. (1999). “Sociolinguistics: An Overview.” In: Adegbija, (ed). The English

[23] Language and Literature in English: An Introductory Handbook. Ilorin: University of Ilorin.

[24] Levinson, Stephen. (1983). Pragmatics. Cambridge: Cambridge University Press.

[25] Pratt, Mary. (1977). Towards a Speech Act Theory of Literary Discourse. Bloomington: Indiana University Press.

[26] Sadock, Jerald. (1974). Towards a Linguistic Theory of Speech Acts. N.Y.: Academic Press Inc.

[27] Searle, John. (1969). Speech Acts: An Essay in the Philosophy of Language. New York: Cambridge University Press.

[28] Sperber, Dan and Wilson, Deindre. (1986). Relevance, Communication and Cognition. United Kingdom: Blackwell Publishing.

[29] Verschueren, Jef. (2000). "Notes on the Role of Metapragmatic Awareness in Language Use." Pragmatics 10 (4): 43956. 